\title{
Giving voice to the Traumatic Event, Spanish Mothers of Stolen Babies. Three Strategies to Silence Mothers during and after the Dictatorship
}

\author{
Carolina Escudero, PhD \\ University of Missouri in Spain \\ Calle Avila 48, office "I". (08005) \\ Barcelona. Spain
}

During the dictatorship in Spain, women's voices were manipulated and silenced using different strategies. Since the end of Franco's dictatorship (1940-1975), the theft of babies has not been recognized by democratic governments as a crime, even though 300,000 babies were stolen. The end of the dictatorship in Spain did not mark a before and after in women's rights for reproductive health.

The purpose of this paper is to first contextualize the theft of babies, then to examine the process of voice and bodily reconstruction through the testimonies of 20 mothers from the Spanish organization SOS BebésRobados Catalunya (SOSBRC), and take into consideration how the workshops based on resilience created an impact in the process of voicing their cases. As a result of this exploratory study, three categories of silence experienced by mothers arise: Silenced Through Medication (STMe); Silenced Through Manipulation (STMa); Silenced through Medication and Manipulation (STMea).

Keywords: Stolen babies - Spain - Silenced mothers - Resilience - Women's health - Reproductive rights

\section{Introduction}

The Spanish dictator, Francisco Franco, made drastic changes to the way the Spanish population could live, think and act from 1939 until 1975. Franco won the Spanish Civil War (1936-39) and established a dictatorship; after the end of the Spanish Civil War,its victims lived under repression; the Republicans (known as the Reds) were terrified during Francoism. Extra-judicial executions had taken place after the Civil War was over, making the Republicans very weary of exposing themselves by denouncing human rights abuses (Valverde, 2012).

During the dictatorship, women were ordered to preserve their chastity and re-conquer the household. Women's chastity was to be considered the most valuable of all feminine virtues, and those women violating in any way these public morals were to be considered a danger to the social order (Morcillo Gómez, 2015, p.193). Throughout Franco's dictatorship, women were silenced and subordinated to men, to medical doctors, to church representatives and to the State. As Bueno-Morales and González-Besteiro pointed out: Women not related to the dictatorship were persecuted, imprisoned and murdered - like many men- but at the same time they also had to face sexual violence, electric shocks and the theft of their children (2018, p.48).

Different instruments were used to silence women, such as the pathologization of their emotions through medical writings as well as their marginalization within the educational, political and labor scene through"moralist" messages.In Franco's propaganda,women were treated as superior beings to men due to their physical virtues (motherhood) and for their moral attributes (sweetness, protection, understanding) dedicated to the providing man, with little patience for listening. The varying elements of silence and manipulation would condition women to be "virgins", wives and mothers.

Even gender roles, justifying male's domination,was presented as law; article 57 of the Civil Code sanctioned, even within marriage, that: "The husband must protect the woman and she must obey him." Until 1958, a woman was not authorized by law to be a guardian or a witness in wills, and a married woman still needed her husband's permission. Women were obliged to stop working once they got married, and only after 1961 were they allowed to continue working, with their husband's permission. In addition, they also needed marital permission for certain business transactions (Barrenechea Lopez; 2018, p.34). Until 1973, single women could not leave the paternal home and become independent before the age of twenty-five. In that sense, the marginalization of women in the labor marketwas justified and more so if it was to obtain positions in the administration of justice. In these cases, it was considered that a woman would jeopardize certain attributes that she should not give up, such as tenderness, delicacy and sensitivity (Women's Political, Professional and Labor Rights Act, 1961; in Ortiz-Heras, 2006, p.9). 
A woman's ideal was designed by the government, a model spread by schools, the Church and the media. NicolásMartin describes the regulation dress code for womenat the time: "with long sleeves or to the elbow, without necklines, with baggy skirts that did not point out the details of the body or monopolize undue attention. The clothes could not be short and much less transparent. Young women should not go out alone or be accompanied by men who were not from the family"(2005, p.149).

In terms of women's bodies and health, the theory of eugenics arosein Spain and in certain aspects corresponded to the aims of Lamarckian or Mendelian eugenics: the homogenization of the population. This led to a rigid and utopian notion of the human body as stable, controllable and beautiful, racially and gender determined (López-Durán, 2018, p.27). The person defending this notion of eugenics was Vallejo Nágera, known as the regime psychiatric, in various books such as "Social Medicine and Mental Hygiene" (1943) and later in "The Wisdom of the Home. Before you get married" (1946). In the first book Nágera explained why the race needed to be cleansed and improved by following his instructions and in the second book he provided moral advice as well as justifications: thatthe precepts of eugenics could prevent morbid offspring (Morcillo Gómez, 2015, p.139).

In summary, Franco, Vallejo Nágera and the Catholic Church worked together to define women's lifestyle by telling them what was good and accepted. In accordance with Gonzalez-Duro (2008), those instructions were the steps prior topsychological brainwashing; having people believe that Republicans and people that were not Catholic deserved to be cast aside and even experimented on so that the "red gene" and other forms of opposition could be eradicated from the community and therefore not infect the Spanish population. Vallejo admired the progress of German geneticists and cited the works of Dubitscher, Luxemburger or Stumpfl, praised in Gütt's manual (1937). However, he had special interest in distancing himself from German eugenics and highlighting the Catholic orthodoxy of his Eugamy:

Our concept of Eugamy separates it very clearly from Eugenics, since it considers the psychic facet of personality in the choice of spouse, so that genotypes of the best qualities result from the crosses (...). Eugenics selects genotypes from biological points of view, with the sole purpose of preventing the transmission of hereditary lines. The Eugamy establishes rules so that the characterological selection of the bride and groom is not made randomly and blindly and in such a way that they transmit to the offspring the characterological qualities suitable for the social prosperity of parents and children" (Vallejo Nágera, 1946, p.201).

Another influential publication from Nágera was the "Marxist fanaticism psychism. Psychological investigations of female criminal Marxists" (1939); in these cases, women were found guilty of having been active in the socio-political sphere, of not adjusting to the traditional model of the woman of the house, submissive, sacrificed and the guardian of the family order. These included the women of the Reds - wives, mothers, daughters - guilty of not having avoided the moral and political ideas of their men.

Faced with past events and the consequences of forty years of dictatorship for the social fabric of Spain, the first social movements integrated by mothers who expressed the need to initiate searches for their children were stereotyped and discredited by the mass media and discouraged by various institutions. However, neither stigma nor discredit has silenced them again. As Manzor-Coats indicates: the collective character of modern-day testimonials brings silence and personal ordeals to the public sphere. The once fragmented or nonexistent subject becomes a public figure in a common collective struggle (1990, p.171).

\section{Babies'appropriation}

In 1940, the theft of children became legal; the government's policy was based on separating babies and children from the "red gene" families. From then on, the practice of stealing babies only became easier and more straightforward. Records show that 9,000 children of political enemies were taken in 1943, and another 12,000 were taken in 1944 (Fotheringham, 2011).

For a better understanding of how the appropriation system worked (accompanied by the manipulation, domination and silencing of mothers) the stolen babies' period can be divided into two: first, the period from the 1960's (political motivation and eugenics, the children were separated from their Republican mothers in prison in an attempt to eradicate any trace of the "red gene" in opposition to Franco). The second period dates from the 1960's until 1999. After the transition to democracy in 1978, the number of stolen babies decreased but continued.

More specifically, between 1940 and 1999 babies were stolen in Spain under the same systematic practice. At the time of their birth, the mothers of these babies were told that they had died from various causes. Nevertheless, between 2009-2011 the families discovered that these babies had been stolen and a long period of silence came to an end. According to victims' testimonies and literature, the theft of babies in hospitals during and after Franco was not committed directly by State agents. The individuals involved were: doctors, midwifes, anesthetists, nuns. They were capable of performing acts that infringed on basic human values and rights following a systematic policy. 
In stolen babies' cases, the term systematic has been understood as either an organized plan in furtherance of a common policy, which follows a regular pattern and results in a continuous commission of acts, or as "patterns of crimes" such that the crimes constitute a "non-accidental repetition of similar criminal conduct on a regular basis" (Katanga and NgudjoloChii, Barrenechea-López, 2017, p.48).

In addition, these patterns of crime are present in the families' testimonies from Andalusia, Catalonia, the Basque Country and even the two British mothers' cases -their babies were stolen during the time they lived in Spain-. All of them confirm the existence of a clear pattern: drugs were administered without the women's consent during labor and even after labor; lack of information about the baby's illness or death, falsification of documents about the babies' deaths or illnesses, falsification of documents in which the adoptive families became the biological ones. BuenoMorales and González-Besteiro developed the modus operandi:

The couple looking to "adopt" a baby would visit the parish priest or chaplain of the church to which they belonged. The priest acted within the network giving support to the family in regard to their discretion, morality, solvency and reliability. In this way, the petition was transferred to a nun who acted as a nurse or social worker of some clinic, maternity or a house for single mothers. After waiting between 7 months and a year, the couple was contacted to go to one of these places and pick up the baby. The baby would be registered as a biological child (2018, p.130).

As Aguilar specifies, the stealing of babies continued in private and public hospitals for some time after democracy,due to the fact that many people working for Franco's regime continued working in public offices during democracy (2013, Barrenechea-López, 2017, p.29). Another reason for that change is related to the adoptions law modified in 1987 (Bueno-Morales and González-Besteiro, 2018, p.157)

By taking into consideration how the systematic theft of babies was organized, a direct impact on families, especially mothers, can be observed as an unresolved traumatic event; if we take intoconsideration the number of families affected by the theft of babies and the number of years in which these systematic thefts occurred, it allows us to corroborate that we are faced with a severe traumatic event as suggested byHerman:

There is a simple, direct relationship between the severity of the trauma and its psychological impact, whether that impact is measured in terms of the number of people affected or the intensity and duration of harm" (1992, p. 57).

\section{PTSD in mothers from Spain}

The effect of exposure to a traumatic event on the health of Stolen Babies' survivors from Spain has not received considerable attention in the literature because the victims are not recognized by the government as victims of a crime against humanity, as suggested by former judge Garzon (2017). Many researches, carried out indiverse sociocultural contexts, show that sociopolitical events of a traumatic nature impact the physical health and quality of life of affected individuals and groups by altering their grieving processes or inducing negative emotions. Iribarren, Prolo, Neagos, Chiappelli defines Post-traumatic stress disorder, or PTSD as: the psychiatric disorder that can result from the experience or witnessing of traumatic or life-threatening events such as terrorist attack, violent crime and abuse, military combat, natural disasters, serious accidents or violent personal assaults (2005, p. 503).

As can be seen in other studies on PTSD, the stress that results from this type of traumatic event precipitates a spectrum of psycho-emotional outcomes such as altering the belief system and modifying the relationship with others and with oneself (Martín Baró, 1990; Lira 1991; Kordon 1995; Beristain 1999; Pederson, 2002; Pérez Sales, 2006, 2012). In addition, many of these impacts not only refer to the traumatic event but also to the context of persecution and impunity in which the survivors have lived (Cabrera, Beristain, Jiménez et al. 2006, in Arnoso-Martínez, Pérez-Sales, 2012). Interms of impunity and in line with this argument, the Guatemalan historical memory report "Never Again" gives importance to the definition of impunity: understood as the absence or insufficiency of investigation, trial and punishment of those responsible for human rights violations, this adds new political and psychosocial implications in the socialfabric to those produced by the traumatic event (ODHAG, 1998).

\section{Methodology}

This research is qualitative with an exploratory descriptive and narrative approach. This study is based on the testimonies of 20 mothers from the SOSBRC movement. Through the observation of their participation in the workshops and actions of group dynamics based on resilience. The workshops of group dynamics were mainly based on empowerment and community resilience. In this work, we take empowerment to be both the psychological sense of control and personal determination and the provision and recognition of rights and new, maybe wider perspectives to options. Adams (1990) considers empowerment a process through which an individual or group acquires resources and control in order to carry out activities or adoptbehavior previously out of their reach (in Hombrados-Mendieta \& Domínguez-Fuentes; 20007, p.39). 
With respect to resilience, it was approached from the perspective of community resilience based on the definition by Landau as "the capacity of a community to uphold hope and faith to resist trauma and major loss, to rise above adversity and to prevail, generally with an increase in resources, skills, connectivity between people and systems." (2004, p.3). Landau's definition corresponds to the characteristics of our study target group because it is based in research and practices focused on mental health, and highlights:

The importance of identifying and developing the inherent strength of individuals and families instead of simply pathologizing weaknesses (Attneave y Verhulst, 1986; Boss, 1991; Figley y McCubbin, 1983a, 1983b; Garbarino y Kostelny, 1996; Imber-Black, 1986; Johnson, 2002; Landau y Saul, 2004; Seligman y Peterson, 2003; Walsh, 2003; Walsh y McGoldrick, 1991). The "Link of Human Systems" Model to promote community resilience (Landau, 2001b, 2002, 2004a, 2004b) takes the concept of resilience to the community level. (2004, p.3)

Activities based in both empowerment and community resilience were situations in which allowed many participants to take part in the campaigns"We Are Looking for You" (known as TEB) (Escudero 2017, 2018), whether in the first or second version. For this investigation, and to address the testimonies of mothers who have suffered obstetric violence, who have been traumatized by the theft of their children, we have taken as a reference authors like Caruth, Avelar, Piglia andSarlowhohaveinvestigated trauma, memory and the (im)possibility of narrating whathappened (van der Vorst, 2013, p.37).

To address the memory of the facts related to the theft of a baby together with the obstetricviolence experienced and the traumatic event seen through different testimonies,similar studies were taken into consideration, such as: Trauma, Memory and Body: the femaletestimony in Colombia (López-Baquero, 2012); Gender and Violence inthe Southern Cone, (Kaplan, 2007) as well as Path of Justice (García del Cid, 2016) and Stolen Babies in Andalusia since 1936 (Bueno-Morales and González-Besteiro, 2018). In the first two studies, the authors focus on the relationship between the female body and memorythrough the testimonial narrative as well as the experience and resilience achieved bymany women to reconstruct their voices and their bodies. The book Path to Justiceis one of those that focuses on more testimonies in which, according to García del Cid, "more than flagrant cases are narrated by and accused by those who, to date, have been legally ignored" (2016, p.13). The work of Bueno-Morales and González-Besteiro, in addition to making a contribution with a gender perspective to the years of the dictatorship, considers that these testimonies and historical facts are necessary in order to relate to "creating awareness of the suffering and violation of human rights suffered both by children victims of forced child disappearances and the sale of human beings throughout the Spanish territory, as those suffered by their authentic families "(2018, p.18).

In terms of testimonies, as Manzor-Coats indicates, testimony is not a new genre in Latin America:

The discursive structure of the Latin American testimonial is reminiscent of the chronicles written as eyewitness events by a learned individual who recorded accounts of atrocities, injustices, and daily practices during the conquest of the New World. The collective character of modern-day testimonials brings silence and personal ordeals to the public sphere. The once fragmented or nonexistent subject becomes a public figure in a common collective struggle (1990, p.157).

\section{Findings}

Through this study, the group dynamics (between 2017-2018) were observed in terms of the participation and actions of twenty SOSBRC mothers and their testimonies were analyzed separately. Different modalities have been observed by which these mothers were silenced during and after labor and from which thesethree categories, integrated by the same component, silence, are presented: a) Silenced through Medication (STMe):women were given medication after having had their baby - sleeping, soothing pills for a maximum duration of three months. Added to this were doctors' recommendations and instructions, such as: remove everything related to the baby from the house, take a trip as a couple, move out of the house or flat and think about the future; b) Silenced through Manipulation (faith, fear, madness) (STMa): in this case the presence of nuns was paramountwith regards to faith and being a "good catholic", "devoted woman" and ready to accept God's decisions; c) Silenced through medication and manipulation (STMea): in this case a combination of the categories listed above is observed.On the one hand the mother is medicated and her family, because the mother is under medication, receives the doctor's/nun's instructions about avoiding the topic, accepting the situation with faith and being ready to have another baby. For each of these silences induced by those who were part of what we have called the systematic theft of babies, we selected part of the testimonies to illustrate the stories. The mothers belonging to the STMe group showed a constant andhigh degree of distrust of the institutions (political, ecclesiastical and public, private health spaces). They avoid visits to the doctor and they remember and show with their bodies the state in which their bodies were at the time of the medication, stating that "I understood everything that happened around me, I was paralyzed, immobilized, I thought the words I couldn't say because I couldn't even open my mouth.

62 
I was aware that my baby had died but I was petrified in my being. The medication did not take away my sadness, it simply meant that I could not put it into words or movements. I even drooled and someone in the family dried it",AP recalls. In this category, there is a great willingness to participate in workshops and exercises, and to remember their story before each meeting.

In the category called STMa we observe that, as in the previous category, there is a high degree of distrust of institutions (political, ecclesiastical and public and private healthspaces) where the degree of rejection is more focused on the Church's representatives. In this group the stories are more diverse: "The nun did not want to help me get out of bed to see my child. She told me that he was monstrous and that he had a few hours to live. I could not move from the pain. I did not see my baby", IM; "The nuns went out to talk to my family and convince them that there was only prayer left; I was still hopeful, alone in that bed", AM; "I had already been told that my baby had died. I was alone in bed trying to understand; then the nuns and a nurse came to see me and took out the milk I had, they told me it was for other babies, they asked me to collaborate with the other mothers. They left me in the hospital, surrounded by other mothers who did have their babies; now I think that my son was drinking my milk, he was there in the other room",DP. "If you are a good Catholic, you know that this child is an angel", AR; "You are lucky that the child has died, he had a malformation in his foot",AP; "You don't have to keep talking about this, people won't believe you. You are young, you can have another child and this will only be a bad memory, nothing more", IG.

In the case of STMea, we find the same characteristics as the previous ones, although not only is there distrust towards institutions (political, ecclesiastical and public and private health spaces) but also a more critical view focused on the lack of justice. These women or their families had to hear instructions like: "Take a trip, get a change of air and in a few months, at least three, try to get pregnant again", MR; "Sheis a young and fertile woman, who can have many more children if shewants to, the death of the first baby is common, you will forget about it",OR; "Make sure that she is taking the medication, she will recover soon, God knows well why the child is not here", JLP; "You must trust the doctor's criteria, he is the one who knows and he shouldn't be questioned", IG.

They consider the lack of historical memory, the lack of recognition of cases and the delay in justice in their country as aspects that will not change, hence it is very difficult for them to develop a resilient position although they end up being caught up in the group and the group actions in pursuit of change. "In Argentina, which is always said to be like the third world, a country in South America, justice was done much faster. Here we continue to drift, our cases do not matter", IA; "They just wait for time to pass, for us to be older, and for us to die taking our cases to the grave", IG.

The STMe and STMa categories are composed of women who participate in all the activities proposed by the organization and the workshops.In the case of women who are part of the STMea category, they are not usually as participatory but when they join the group they become open, receptive and empathetic towards others. After the presentation of the first TEB campaign (2017, Escudero), more people came to the group after observing the mothers' first-person accounts and this encouraged them to "trust and know that I was not alone", NC.

A characteristic found in all three categories is that after the theft of a baby, all of the womenwere able to get pregnant and become mothers again. After the theft (what for them at the time was the death of the baby) they all let time go by and then they gave birth to a baby.Yet many of those interviewed said that during their second pregnancy they were extremely worried and, in some cases, "anxious" about the possibility of their new baby dying as they believed had happened to the first. The women integrating the three categories recognize and agree that to have been mothers meant immense joy even though "we do not forget the baby that was stolen", NC.

\section{Conclusions}

The workshops attended by the SOSBRC mothersbased on resilience represent the beginning of an individual and group reconstruction;sharingeach other'stestimonies, it has been possible to move towards a process of reconstruction of life itself as well as the unification of a search with diverse voices that together demand justice, memory and reparation. Although the repair, in this case, arises from group work and not from theimplicated institutions. The fact that the reparation is initiated from a resilient perspective allows the group to become aware of the years of silence and of the need to recover their memories and words. Each woman initiates her search from a creative starting point, which allows her, by telling her story in the first-person, to begin her search from a safe place, firstly individually and then as part of group in which trust in oneself and in the other group members fosters an attitude of resilience. This acquired space of experiences becomes a space so safe that she has the strength and energy to open herself to the world through social media in which the voices are identified by case and at the same time, united within the two TEB campaigns (2017, 2018). Hence both initiatives arise in the context of a Spanish state that since the advent of democracy, continues to neither recognize these cases nor make progress in their reparation or the recognition of the victims, considered a means of silencing the past and the present. Going back to the importance of the voices, in unison or as a group, they correspond to that observed by Herman: 
The solidarity of a group provides the strongest protection against terror and despair and the strongest antidote to traumatic experience. Trauma isolates; the group recreates a sense of belonging. Trauma shames and stigmatizes; the group bears witness and affirms. Trauma degrades the victim; the group exalts her. Trauma dehumanizes the victim; the group restores her humanity"(1992, p.223).

In conclusion, the emergence of SOSBRC mothers in the media through two campaigns (TEB 2017, 2018) is an element of breaking a paralyzing silence present during and after the dictatorship, a silence that many mothers have dared to break but that many more have not yet done so.The process of giving voice to their own cases is a way to transcend the "this is not said." As Herman suggests: sharing the traumatic experience with others is a precondition for the restitution of a sense of a meaningful world (1992). By communicating their stories, the Spanish mothers from Catalonia have begun the process of truth: mitigating the pain and dignifying themselves.

\section{References}

Arnoso-Martínez, M., Pérez-Sales, P. (2012) Argentina (1976-1983): Impacto y Afrontamiento Psicosocial de la Violencia Represiva. XIII Congreso Virtual de Psiquiatría.com. Interpsiquis14: 1-6. Available at: https://doi.org/10.11144/Javeriana.upsy14-3.aiap

Barrenechea López, G. (2018) Gender in Transitional Justice Conetxts: Reproductive Rights in the Spanish Case of Stolen Babies. Master Thesis. Faculty of Law, Lund University. Available at: https://lup.lub.lu.se/studentpapers/search/publication/8919469

Bueno-Morales, M. , González-Besteiro, J (2018) Bebés Robados en Andalucía desde 1936. Buscando la Verdad, la justicia y la reparación. [Stolen babies in Andalusia since 1936. Looking for Truth, justice and reparation.] Andalucia: Ed. Dirección General de Memoria Democrática. Junta de Andalucía.

Confilegal, (2017) "El robo de bebés durante el franquismo es un crimen de lesa humanidad", según Baltasar Garzón. Available at: https://confilegal.com/20170719-robo-bebes-franquismo-crimen-lesa-humanidad-segun-baltasargarzon/

Escudero, C. (2017) Te Estamos Buscando, TEB campaign. Consulted 12 February, 2020. Available at: https://www.youtube.com/watch?v=MfOMKmqKgsM

Escudero, C (2018) Te Estamos Buscando, TEB campaign. Consulted 12 February, 2020. Available at: https://www.youtube.com/watch?v=G0D6Txc08hU

Fothresingham, A. (2011) The 30.000 lost children of the Franco years are set to be saved from oblivion. The Independent.Consulted 19 February, 2020. Available at:

https://www.independent.co.uk/news/world/europe/the-30000-lost-childrenof-the-franco-years-are-set-to-besaved-from-oblivion-2173996.html

García del Cid, C. (2016) Camino de la Justicia. Madrid: Nuevo Agora.

González-Duro, E. (2008) Los psiquiatras de Franco, Los rojos no estaban locos. Barcelona: Ediciones Península

Gütt, A. (1937). Handbuch der Erbkrankheiten. [Manual de enfermedades hereditarias] Leipzig: Thieme.

Herman, J.L, (1992) Trauma and Recovery. From domestic abuse to political terror.London: Pandora Ed.

Hombrados-Mendieta, M.I., \& Domínguez-Fuentes, J.M., (2007) La potenciación comunitaria (Empowerment) en Estrategias de la intervención psicosocial: casos prácticos / coord. por Maya-Jariego, I. Manuel García Ramírez, Santolaya Soriano, F.J., 2007, ISBN 978-84-368-2144-4, págs. 39-43

Iribarren,J., Prolo, P., Neagos, N., Chiappelli, F. (2005) Post-Traumatic Stress Disorder: Evidence-Based Research for the Third Millennium; Evid Based Complement Alternat Med. 2005 Dec. 503-512. Consulted22February, 2020. Available at: https://www.ncbi.nlm.nih.gov/pmc/articles/PMC1297500

Kaplan, B (2007) Género y Violencia en la narrativa del Cono Sur (1954-2003). New York: Boydell\&Brewer.

Landau, J. (2005) El modelo LINC: una estrategia colaborativa para la resiliencia comunitaria. SistemasFamiliares, 20 (3). (The LINC Model. A collaborative Strategy for Community Resilience); Bourlder, Colorado. www.elibro.com. Consulted19February, 2020. Available at: https://view.publitas.com/arise-network/the-linc-modela-collaborative-strategy-for-community-resilience/page/1

López-Baquero, C (2012) Trauma, memoria y cuerpo. El testimonio femenino en Colombia (1985-2000). España: Asociación Internacional de Literatura y Cultura Femenina Hispánica (AILCFH).

López-Durán, F. (2018) Eugenics in the Garden, Transatlantic Architecture and the Crafting of Modernity. University of Texas Press. Austin, Texas.

ODHAG. Guatemala Nunca Más. Los mecanismos del Horror. Guatemala: Oficina de Derechos humanos del Arzobispado de Guatemala. Consulted 19February, 2020. Available at: https://www.odhag.org.gt/html/Default.htm 
Manzor-Coats, L (1990) The Reconstructed Subject: Women's Testimonials as Voices of Resistance in Lucía Guerra Cunningham, Ed. Splintering Darkness: Latin American Women and Writers in Search of Themselves. Pittsburg: Latin American Literary Review Press

Morcillo Gómez, A (2015) En cuerpo y alma: ser mujer en tiempos de Franco. Madrid: Siglo XXI de España Editores, S.A.

Nicolás Marín, E (2005) La libertad encadenada. España en la dictadura franquista 1939 - 1975. Madrid: Alianza.

Ortiz_Heras, M. (2006) Aposta. Revista de ciencias sociales. N. 28, 2006. Consulted21February, 2020. Available at: http://www.apostadigital.com/revistav3/hemeroteca/ortizheras.pdf

Vallejo Nágera, A., \& Martínez, E. (1939). Psiquismo del fanatismo marxista. Investigaciones psicológicas en marxistas femeninos delincuentes. Revista Española de Medicina y Cirugía de Guerra, 9, 398-413.

Vallejo Nágera, A. (1946). El matrimonio y las enfermedades psíquicas. SemanaMédica Española, 9(363), 199-204.

Valverde, E. (2012) Constructing victimhood in post-Franco's Spain: The recovery of memory by the grandchildren of victims of the civil war and dictatorship.

Van der Vorst, A (2013) Resistencia nómada en la narrativa testimonial argentina: un análisis de Alicia Partnoy's "The Little School". Available at:

https://webcache.googleusercontent.com/search?q=cache:cLqY19GE_xYJ:https://dspace.library.uu.nl/bitstream/handle/ 1874/288436/Trabajo\%2520Final\%2520Bachelor\%2520Arta\%2520van\%2520der\%2520Vorst.pdf\%3Fsequen ce\%3D2\%26isAllowed\%3Dy+\&cd=16\&hl=es\&ct=clnk\&gl=es 